\title{
PENGEMBANGAN BUKU SAKU BIOLOGI BERORIENTASI KEUNGGULAN LOKAL UNTUK MENINGKATKAN KARAKTER PESERTA DIDIK
}

\author{
Tri Sari Wijayanti \\ SMA Negeri 1 Labuapi, Kabupaten Lombok Barat, Provinsi NTB \\ trisariwijayanti@yahoo.co.id
}

Abstrak: Penelitian ini bertujuan untuk mengembangkan media pembelajaran berupa Buku Saku Biologi berorientasi keunggulan lokal untuk meningkatkan karakter siswa. Penelitian ini merupakan jenis penelitian pengembangan atau Research and Development (R\&D). Model pengembangan yang meliputi 5 tahap yaitu: analisis (analysis), perancangan (design), pengembangan (development), implementasi (implementation), dan evaluasi (evaluation). Pada tahap Development, Buku Saku Biologi dinilai kelayakannya oleh peserta didik Kelas X IPA 1 dan X IPA 2 SMA Negeri 1 Labuapi, Kabupaten Lombok Barat. Pengumpulan data menggunakan analisis deskriptif kuantitatif dan analisis deskriptif kualitatif. Hasil penelitian melalui perhitungan statistik menghasilkan nilai t_hitung=3,585 pada taraf keyakinan 95\% dan df 18, dan t_tabel= 1,734. Karena t_hitung>t_tabel maka dapat dikatakan signifikan responden merasakan perubahan sikap, sifat dan karakter yang lebih baik setelah memahami isi Buku Saku Biologi.

Kata kunci: Buku Saku, Keunggulan Lokal, Karakter

\section{PENDAHULUAN}

Perkembangan pendidikan akan seiring sejalan dengan dinamika masyarakatnya, karena ciri masyarakat selalu berkembang. Hal ini disebabkan pengaruh dari perkembangan teknologi, komunikasi dan telekomunikasi. Dalam kondisi seperti ini perubahan-perubahan dimasyarakat terjadi pada semua aspek kehidupan. Efek perubahan masyarakat akan berimbas pada setiap individu masyarakat, pengetahuan, kecakapan sikap, kebiasaan bahkan pola-pola kehidupan.

Keunggulan lokal dijadikan sebagai orientasi utama dalam pengembangan buku saku karena hal ini sangat dimungkinkan dengan adanya desentralisasi kebijakan pendidikan. Daerah dapat mengembangkan potensi wilayahnya sesuai dengan situasi dan kondisi setempat. Salah satu kebijakan yang dapat dikembangkan adalah membuat kurikulum sekolah yang berbasis keunggulan lokal. Dengan keberagaman potensi daerah ini pengembangan potensi dan keunggulan daerah perlu mendapatkan perhatian secara khusus bagi pemerintah daerah sehingga anak-anak didik di daerah tidak asing dengan daerahnya sendiri dan faham betul tentang potensi dan nilai-nilai serta budaya daerahnya sendiri, sehingga anak-anak dapat mengembangkan dan memberdayakan potensi daerahnya.

Buku merupakan media yang dapat dipergunakan sebagai bahan ajar. Diperkuat dalam penelitian (Wijiningsih \& Wahjoedi, 2017) bahwa dalam rangka memotivasi belajar peserta didik guru dapat memilih media pembelajaran yang bervariasi, agar pembelajaran yang disampaikan akan lebih bermakna. Salah satu usaha untuk meningkatkan yaitu penyediaan sumber belajar peserta didik disekolah dengan menggunakan buku ajar lain sebagai penunjang buku paket terbitan dari kemendikbud dalam pembelajaran. Guru dapat mengembangkan buku ajar yang sesuai dengan kehidupan sosial dan budaya. Pendapat tersebut sejalan dengan (Windyariani, 2016) bahwa bahan ajar dibuat dengan mengintegrasikan dimensi literasi sains, memuat tugas atau kegiatan, menyajikan ilustrasi atau gambar yang menarik. Sementara itu, ciri-ciri buku ajar menggunakan bahasa yang mudah dipahami, menarik, isi yang terdapat pada buku disusun 
berdasarkan kurikulum pendidikan yang berlaku dan isi buku sesuai dengan ide penulis. Menyusun buku ajar yang sesuai dengan kebutuhan peserta didik menganjurkan guru mengelola lingkungan belajar yang memadukan pengalaman belajar yang meliputi lingkungan sosial, budaya, dan fisik sebagai bahan untuk mewujudkan tujuan dari pembelajaran tersebut. Guru juga harus tepat dan selektif dalam mengunakan sumber belajar yang digunakan dalam pembelajaran. Guru juga dapat memanfaatkan media maupun model pembelajaran sesuai dengan materi, agar peserta didik tertarik serta antusias dalam kegiatan pembelajaran. Dari pernyataan tersebut sejalan dengan (Rohmah, 2017) buku ajar yang berbasis kontekstual akan menjadikan pembelajaran lebih bermakna dan tujuan pembelajaran dapat tercapai.

\section{Identifikasi dan Perumusan Masalah}

Adapun identifikasi dan perumusan masalah sebagai berikut: Bagaimanakah model buku saku Biologi berorientasi keunggulan lokal yang dapat meningkatkan karakter peserta didik?

Tujuan berikut :

Untuk itu tujuan pembuatan sebagai

1. Mengembangkan model buku saku Bioloi berorientasi keunggulan lokal melalui integrasi pembelajaran sains berbasis Salingtemas

2. Mendeskripsikan materi-materi sains yang berbasis Salingtemas pada kurikulum 2013 SMA yang dapat diintegrasikan ke dalam buku saku Biologi yang berorientasi keunggulan lokal.

3. Mendeskripsikan aktifitas peserta didik dalam pembelajaran buku saku Biologi berorientasi keunggulan lokal melalui integrasi materi sains berbasis Salingtemas dalam kurikulum 2013 SMA

4. Mengetahui dan menjelaskan beberapa flora unggulan sebagai sumber daya alam lokal di Taman Wisata Alam Suranadi.

\section{Manfaat}

Pembuatan ini bermanfaat sebagai alternatif model pembelajaran sains yang bervisi Salingtemas sehingga dapat menunjang pembelajaran sains secara reguler. Khusus bagi guru, hasil penelitian dapat digunakan sebagai pedoman untuk membangkitkan dan mengembangkan model pembelajaran sains lainnya berbasis Salingtemas.

\section{METODE PENELITIAN}

\section{Waktu dan Tempat Penelitian}

Penelitian dilaksanakan pada bulan Juli sampai dengan Agustus 2019 bertempat di SMA Negeri 1 Labuapi, Kabupaten Lombok Barat. Penelitian dilaksanakan di dua kelas yaitu Kelas X IPA 1 dan X IPA 2. Penelitian ini bersifat kualitatif dengan memberikan angket respon peserta didik setelah diberikan Buku Saku Biologi.

\section{Jenis Penelitian}

Penelitian ini menggunakan metode penelitian dan pengembangan atau Research and Development $(R \& D)$. Menurut Sugiyono (2012) bahwa metode penelitian dan pengembangan digunakan untuk menghasilkan produk tertentu dan menguji keefektifan produk tersebut. Penelitian dan pengembangan adalah suatu proses atau langkah-langkah untuk mengembangkan suatu produk baru atau menyempurnakan produk yang telah ada yang dapat dipertanggungjawabkan, menghasilkan produk tertentu dan menguji keefektifannya untuk mengembangkan suatu produk baru.

Dalam penelitian dan pengembangan ini peneliti melakukan pengembangan buku saku Biologi sebagai media pembelajaran. Produk buku saku Biologi kemudian diujikan pada peserta didik untuk meningkatkan motivasi belajar. Data yang akan dikumpulkan dalam penelitian ini terdiri dari dua data yaitu data kuantitatif dan data kualitatif yang merupakan data mengenai proses pengembangan buku saku sebagai media pembelajaran berupa kritik dan saran guru Biologi, dan peserta didik.

\section{Prosedur Penelitian}

Prosedur penelitian ini mengacu pada model pengembangan ADDIE, yaitu model pengembangan yang terdiri dari lima tahapan antara lain : Analysis (analisis), Design (perancangan), (pengembangan), Implementation 
(implementasi), dan Evaluation (evaluasi). Model pengembangan ADDIE dikembangkan oleh Dick and Carey.

\section{Tahap Analisis (Analysis)}

Pada tahap awal ini dilakukan pengamatan dan pengumpulan data mengenai kebutuhan peserta didik untuk menemukan masalah dan solusi yang tepat dalam pembelajaran. Analisis yang dilakukan pada tahap ini antara lain :

a) Analisis kurikulum

Pada SMA Negeri 1 Labuapi, Lombok Barat menggunakan Kurikulum 2013 pada tahun ajaran 2019/2020. Dalam Kurikulum 2013, guru bertindak sebagai fasilitator, mediator, motivator, inspirator dan peserta didik sebagai subjek dalam pembelajaran.

b) Analisis kebutuhan peserta didik

Berdasarkan hasil pengamatan, diketahui bahwa peserta didik membutuhkan media pembelajaran untuk mempermudah proses pembelajaran. Buku paket yang disediakan oleh sekolah belum digunakan secara maksimal dalam pembelajaran. Diperlukan media yang lain untuk mempermudah peningkatan kompetensi peserta didik.

c) Analisis materi pelajaran Biologi

Materi pelajaran Biologi tidak hanya sebatas materi hafalan saja. Dalam mata pelajaran Biologi, peserta didik akan mempelajari materi-materi yagn berkaitan langsung dengan kehidupan sehari-hari.

d) Merumuskan tujuan

Peneliti berharap dengan adanya pengembangan media berupa buku saku dapat memenuhi kebutuhan peserta didik SMA Negeri 1 Labuapi, Lombok Barat. Selain itu, pengembangan buku saku dapat menjadi alternatif media pembelajaran bagi guru.

2. Tahap Perancangan (Design)

Pada tahap kedua ini dilakukan perancangan untuk media yang akan dikembangkan. Rancangan produk buku saku meliputi tampilan, bahasa, ukuran dan materi yang disesuaikan oleh Kompetensi Dasar. Buku saku dirancang dengan tampilan yang menarik dan bahasa yang mudah dipahami oleh peserta didik, serta berisi yang praktis. Pada tahap ini rancangan buku saku sebagai media pembelajaran masih berbentuk kerangka dan mendasari langkah pengembangan selanjutnya.

3. Tahap Pengembangan (Development)

Pada tahap pengembangan ini dilakukan pembuatan buku saku yang akan digunakan sebagai media pembelajaran. Pembuatan buku saku meliputi kegiatan pencetakan dan penjilidan produk sesuai dengan rancangan model. Penulis juga membuat instrument untuk mengukur kinerja produk buku saku. Proses validasi menghasilkan saran, komentar, dan masukan yang dapat digunakan sebagai dasar untuk melakukan analisis dan revisi media yang dikembangkan. Penyuntingan tersebut bertujuan untuk menghindari kesalahankesalahan dalam buku saku seperti kesalahan isi, kesalahan bahasa, dan kesalahan penyajian.

4. Tahap Implementasi (Impementation)

Produk buku saku yang telah direvisi dan dinyatakan layak, selanjutnya diterapkan pada kondisi yang sebenarnya. Materi yang disampaikan sesuai dengan media baru yang dikembangkan. Tahap ini bertujuan untuk mengetahui respon peserta didik terhadap penggunaan buku saku sebagai media pembelajaran. Uji coba yang dilakukan adalah uji coba terbatas untuk mengukur kelayakan buku saku.

5. Evaluasi (Evaluation)

Pada tahap ini dilakukan evaluasi produk buku saku secara keseluruhan untuk mengukur ketercapaian tujuan pengembangan produk. Revisi dilakukan berdasarkan hasil evaluasi untuk menyempurnakan media yang dikembangkan sesuai dengan kebutuhan peserta didik.

\section{Teknik Pengumpulan Data}

Penelitian ini dalam melakukan pengumpulan data menggunakan teknik antara lain : Menurut Sugiyono (2012), kuesioner merupakan teknik pengumpulan data yang dilakukan dengan cara memberi seperangkat pertanyaan atau pertanyaan tertulis kepada responden untuk dijawabnya. Angket digunakan untuk mengukur kualitas 
media yang dikembangkan. Angket yang digunakan ada 2 (dua) macam yaitu angket validasi dan angket respon peserta didik. Angket validasi diisi oleh tim validator yang terdiri dari ahli materi dan ahli media. Sedangkan angket respon peserta didik digunakan untuk mengukur motivasi belajar.

\section{PEMBAHASAN}

\section{Analisis Kuantitatif dan Kualitatif Buku Saku Biologi}

Analisis kuantitatif dan kualitatif dilakukan setelah buku saku sekolah tersusun. Pengamatan dilakukan dengan memberikan angket pendapat peserta didik sebagai subyek utama tentang buku saku Biologi. Angket dibuat dengan memberikan pernyataan dalam skala Likert. Berdasarkan hasil angket yang diberikan, secara kuantitatif dapat dianalisis sebagai berikut:

Sebanyak $88 \%$ responden mengatakan bahwa sangat setuju, selalu tertarik untuk selalu membaca Buku Saku Biologi. Namun tidak semua peserta didik hanya mengharapkan Buku Saku Biologi sebagai satu-satunya media informasi. Hal ini sangat dimungkinkan terjadi karena responden memiliki media yang lain, misalnya buku paket, buku penunjang dan lain sebagainya. Buku Saku Biologi yang dibuat sangat mudah dipahami, namun dalam pembuatannya $79 \%$ responden berharap adanya perubahan desain, sehingga Buku Saku Biologi memiliki kemenarikan. Pembuatan Buku Saku Biologi juga tidak sembarang waktu, namun melihat situasi, kondisi yang tepat agar sasaran menerima pengetahuan dengan baik.

\section{Analisis Hubungan Antara Buku Saku Biologi dengan Perubahan Karakter Peserta Didik}

Berdasarkan Lampiran 1, nampak bahwa bahwa hasil dari pernyataan 5 menyatakan bahwa responden memahami kompetensi yang ada dan diharapkan dalam Buku Saku Biologi. Artinya gambar dan tulisan yang terdapat pada Buku Saku Biologi dapat ditangkap oleh peserta didik sebagai respoden dengan baik. Melihat hasil perhitungan uji $t$, didapatkan $t_{\text {hitung }}=2,334$ pada taraf keyakinan $95 \%$ dan df 18, dan $t_{\text {tabel }}=1,734$. Karena $t_{\text {hitung }}>t_{\text {tabel }}$ maka dapat dikatakan ada pengaruh Buku Saku Biologi terhadap karakter responden. Kondisi tersebut didukung oleh pernyataan no 1 tentang penguatan pendidikan karakter dalam pembelajaran IPA.

Sebanyak $83 \%$ responden selalu malakukan refleksi setelah melihat Buku Saku Biologi. Perhitungan menggunakan uji $t$ terlihat bahwa nilai $t_{\text {hitung }}=2,800$ pada taraf keyakinan $95 \%$ dan df 18 , dan $t_{\text {tabel }}=1,734$. Karena $t_{\text {hitung }}>t_{\text {tabel }}$ maka dapat dikatakan signifikan responden selalu melakukan refleksi diri setelah melihat Buku Saku Biologi. Hasil akhir yang diharapkan pada peserta didik terungkap dengan pernyataan nomor 10 bahwa sebanyak $83 \%$ responden sangat setuju dan merasakan perubahan sikap, sifat dan karakter yang lebih baik setelah melihat dan memahami isi Buku Saku Biologi. Perhitungan statistik menghasilkan nilai $t_{\text {hitung }}=3,585$ pada taraf keyakinan $95 \%$ dan df 18 , dan $t_{\text {tabel }}=1,734$. Karena $t_{\text {hitung }}>$ $t_{\text {tabel }}$ maka dapat dikatakan signifikan responden merasakan perubahan sikap, sifat dan karakter yang lebih baik setelah memahami isi Buku Saku Biologi.

$$
\text { Perhitungan statistik tentang }
$$

keberadaan Buku Saku Biologi, respoden memberikan penilaian dalam skala Likert. Secara grafis hasil angket dapat digambarkan dalam histogram seperti yang terdapat pada Gambar berikut.

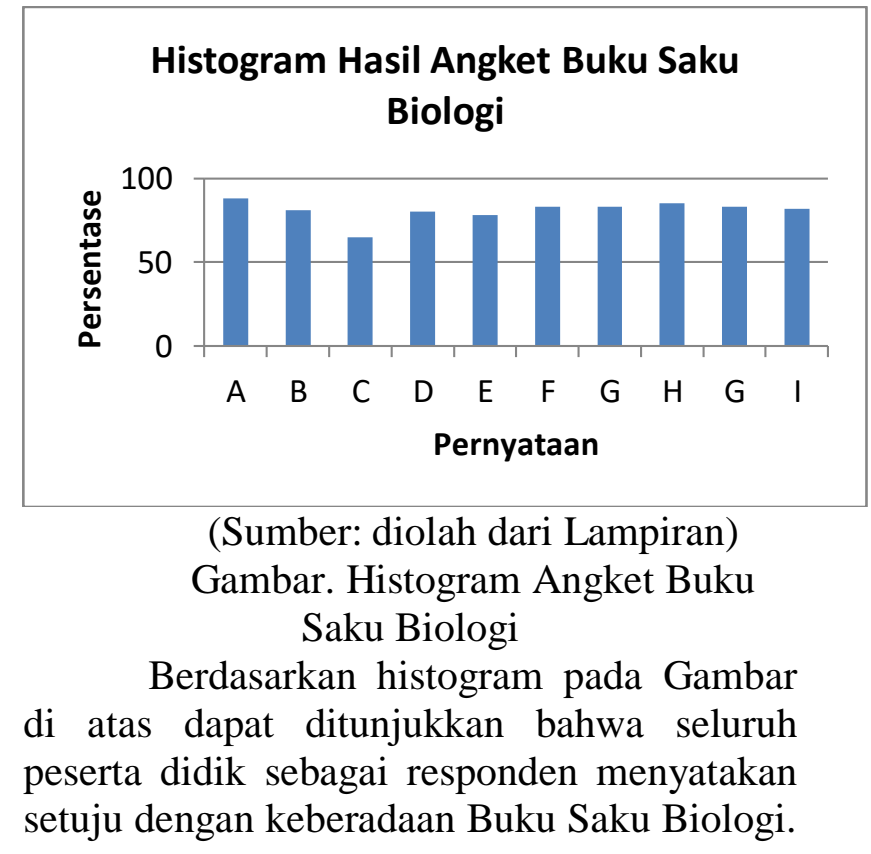


Hal ini sependapat dengan Melyanti (2017)

(2), $19-25$. bahwa peserta didik memberikan respon yang layak pada buku saku Biologi berbasis mind mapping. Penelitian yang dilakukan Segoro (2019) juga menyimpulkan bahwa buku ajar yang bermuatan lokal sangat efektif untuk peningkatan hasil belajar.

\section{KESIMPULAN}

Berdasarkan hasil penelitian pengembangan dan pembahasan dapat disimpulkan bahwa:

1. Pengembangan Buku Saku Biologi melalui 5 tahapan yaitu: analisis, perancangan, pengembangan, implementasi dan evaluasi.

2. Adanya perubahan sikap, sifat dan karakter yang lebih baik setelah memahami isi Buku Saku Biologi.

Adapun saran yang dapat diberikan adalah:

1. Materi pada buku saku Biologi dapat dikembangkan dengan menambahkan contoh materi yang sesuai dengan kehidupan sehari-hari.

2. Perlu dilakukan penelitian lebih lanjut mengenai motivasi belajar siswa terhadap penggunaan media pembelajaran buku saku berbasis keunggulan lokal.

\section{DAFTAR PUSTAKA}

Melyanti, Sri (2017) Pengembangan Media

Pembelajaran Buku Saku Berbasis

Mind Mapping Untuk Pembelajaran

Ekonomi Kelas XI.

http://eprints.unm.ac.id/14361/1/Jurnal $\% 20$ Sri\%20Melyanti.pdf

Rohmah, D. F., Hariyono., \& Sudarmiatin. (2017). Pengembangan Buku Ajar IPS SD Berbasis Kontekstual. Jurnal Pendidikan: Teori, Penelitian, dan Pengembangan, 2(5), 719-723.

Sugiyono. 2012. Metode Penelitian Pendidikan : Pendekatan Kuantitatif, Kualitatif dan R\&D. Bandung : Alfabeta

Wijiningsih, N., \& Wahjoedi. (2017). Pengembangan Bahan Ajar Tematik Berbasis Budaya Lokal, 2, 1030-1036. Windyariani, S., Setiono., \& Sutisnawati, A. (2016). Pengembangan Bahan Ajar Berbasis Konteks dan Kreativitas untuk Melatihkan Literasi Sains Siswa Sekolah Dasar. Jurnal Bioedukatika, http://dx.doi.org/10.26555/bioedukatik a.v4i2.5326 